\title{
RUSSIA IN THE MODERNIZATION: FINANCIAL ASPECT
}

\author{
RUSIJA U MODERNIZACIJI: \\ FINANSIJSKI ASPEKT
}

\section{Ludmila Prigoda}

Maikop State Technological University, Maikop, Russia

(C) MESTE NGO

JEL category: E6, E62, $0,01,04$

\begin{abstract}
This work represents an attempt to understand a current crisis situation that takes place in the world economic space. The reasons for the world crisis as well as the prospects of the further development of the Russian economy are also considered. Regarding Russia, the authors have concluded that the innovative breakthrough strategy is grounded on a number of monographs and drafts of long-term programs, but by this time these recommendations have not received an adequate response from the government. Russia needs a real, not virtual (conservative) modernization, providing a radical innovation upgrade and the increase in competitiveness of the technological base of the economy. Over the past two decades, Russia has experienced several types of innovations, including antiinnovations (the reforms of the early 1990's of the last century) and pseudo-innovations (the attempts of a partial improvement of outdated technologies). It is time to go to the basic innovations that can lead to radical changes in the decades to come, and become a platform of epochal innovation developments that can provide a breakthrough on a time scale of centuries.
\end{abstract}

Keywords: world crisis, world civilizations, prospects for development, modernization.

\section{Apstrakt:}

Ovaj rad predstavlja pokušaj da se pojasni trenutna kriza koja vlada u svetskom ekonomskom prostoru. Takođe, razmatraju se i razlozi svetske krize, kao i perspektive daljeg razvoja ruske privrede. Što se tiče Rusije, autorka je zaključila da inovativna

The address of the author:

Ludmila Prigoda

莑=" Iv_prigoda@mail.ru strategija napretka treba da se zasniva na nekoliko objavljenih monografija i nacrta dugoročnih programa razvoja, ali i da ovaj put te preporuke nisu dobile adekvatan odgovor od strane vlade. Rusiji je potrebna prava, ne 
virtuelna (konzervativna) modernizacija, koja obezbeđuje radikalnu inovativnu nadgradnju i povećanje konkurentnosti tehnološke baze privrede. Tokom protekle dve decenije, Rusija je doživela nekoliko tipova inovacija, uključujući i anti-inovacije (reforme početkom 90-ih godina prošlog veka) i pseudoinovacije (pokušaji delimičnog poboljšanja davno zastarelih tehnologija). Autorka smatra da je došlo vreme da se ide do suštinskih, osnovnih, inovacija koje mogu da dovedu do radikalnih promena u decenijama koje dolaze, $i$ da postanu platforma epohalnog inovacionog razvoja koja može da obezbedi krupan iskorak u vremenima koja dolaze.

Ključne reči: Svetska kriza, svetske civilizacije, perspektive razvoja, modernizacija.

\section{INTRODUCTION}

The global crisis of 2008 moved from financial to economic, social and other spheres. It showed that an inertial model of the development invariably lead to uncertainty and collapse. It's high time to understand the historical paradigms and build an integrated model of the economic development under which the market competitive economy will be combined with the principles of solidarity and mutual confidence.

Today, however, the lack of clear guidance of the development of the world economy as well as strategic plans for the development of the world civilization doesn't allow us to coordinate the efforts of all participants of the global economic space. These efforts should alleviate the crisis, prevent conflicts and disasters and optimize the process of progressive development.

The current global financial and economic crisis is another step in the transformation of the economic system and decline of industrial system, the descending phase of the fifth Kondratieff cycle. In 2006 a number of scientists predicted the inevitability of a global economic crisis. (Volkova, 2010) This was evidenced by the growth of parasitism of the late industrial economic system and the neoliberal model of globalization, the decline of average annual global GDP and labor productivity, the growing gap between few rich and a lot of poor countries. The prediction showed the beginning of a crisis phase of the long-term (Kondratieff) and ultralong-term (civilization) cycles in the dynamics of the world economy. Doctor of Economic Sciences, the president of the Association "Predictions and Cycles" Yuri Yakovets has an interesting approach to this. He developed the original methodology of integrated prognostics at the macro level that stands on four pillars: the theories of crisis cycles and innovations made by

Nikolai Kondratieff and Joseph Schumpeter, the civilizational approach to the past and future made by Pitirim Sorokin, Arnold Toynbee and Fernand Braudel, the doctrine of the noosphere made by Vladimir Vernadsky and Nikita Moiseyev and the balance method of prognostics at the macro level made by Wassily Leontief. (Davydov \& Grebenichenko, 2010) This methodology significantly differs from the widespread foresight methodology that is more suitable for predicting microeconomics. Unlike most of the published long-term predictions, this methodology is based on the assumption that "... at the turn of the millennium bicentennial cycle of the industrial world civilization, five hundred year cycle of the fourth generation of local civilizations will be completed. (Kvasov, 2010) They transpierce the entire structure of civilizations and find expression in a cluster of complementary resonating crises: demographic, energy and environmental, food crisis, technological, geopolitical and socio-cultural". As expected, this polymorphic turmoil will continue until the 20 's of the XXI century, i.e. until the beginning of an upward wave of the Kondratieff cycle and the further innovation breakthrough or, in other words, the epochal innovations. (Blinov, Zakharov, \& Zakharov, 2012)

As the history of the world development shows, the changing of world civilizations happens regularly. Every a few centuries one civilization displaces the other (Fig. 1).

Humanistically noospheric or integrated civilization should be based on the best achievements of all previous civilizations, and should be a synthesis of cultural, economic, legal, political and other achievements of the world community. This civilization should create the conditions under which the market 
competitive economy will be combined with the principles of solidarity and mutual confidence between the participants of economic relations.
However such transformations should involve a full-scale replacement of development priorities, but not a surface upgrade in relationships.

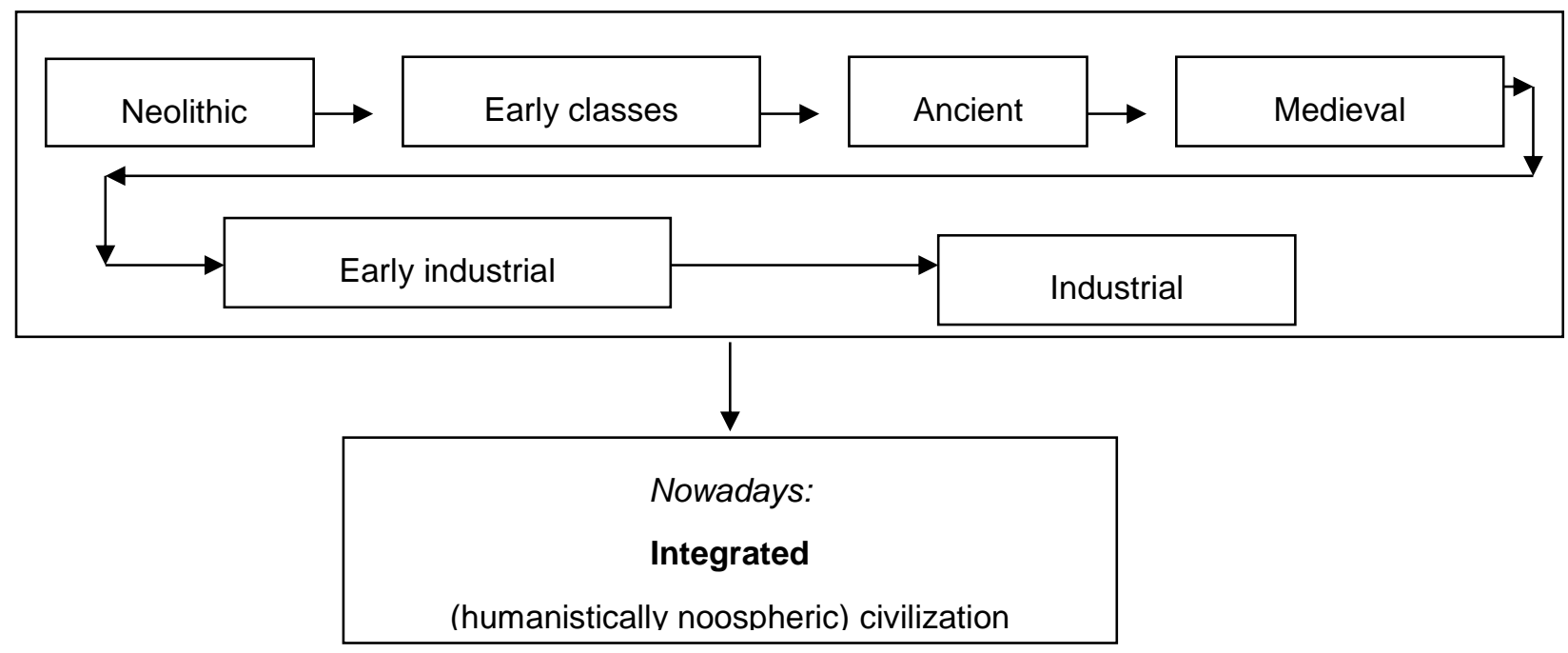

Fig. 1 The evolution of world civilizations

The transition to a new phase of development will undoubtedly lead to a change of locomotive (driver, avant-garde, authority, leadership, etc.), that, according to many economists and politicians, in the next decade could be the Chinese civilization that has managed to unite the achievements of capitalism and socialism. China is a country situated on the rise: the government demonstrates the efficiency, the industry is developing dynamically, and intellectual capacity is growing rapidly. At the same time, the lack of natural resources and territories, the excess of population and the lack of intellectual capacity create some difficulties for the further enhance of the growth rate of the area.

\section{RUSSIA'S ECONOMY}

As regards Russia, predictions are very different. As we know, for every process bifurcation points are typical. It is a kind of crossroads of possible directions for further development, including steep turns, in which the uniform (linear, evolutionary) part of the trajectory abruptly changes the direction. Based on the optimistic predictions of development in Russia, a turn at the bifurcation point will start due to the emergence of new factors (in particular, radical innovations), which will allow to change dramatically the direction of the development. If in fact, the strategy of innovative breakthrough is selected and implemented, powers of science, business, education and government I focus on the development and dissemination of basic innovations of the 6th technological order, then Russia will have a chance to carry out a radical innovative modernization of leading branches of the economy based on still remaining intellectual potential, to achieve leadership in some innovative ways and improvement of the competitiveness of products in the domestic and foreign markets. The implementation of this scenario requires strategic thinking and actions, high professionalism of scientific, business and the ruling elite. However, the country that was once a leader in the technological development and a second super state in the world today is dramatically losing positions in industries that are called the economy of knowledge, the economy of intelligence.

In the coming years the main challenge in the economic sector is a need for repositioning of Russia in the world economy. Raw material specialization can provide neither sustainable improvement of the level and quality of life, nor the formation of a new style of life. The development of the country should be based on the usage of three main competitive advantages: resource potential, territorial potential and 
creativity of people. Today only the first group of benefits is actively involved. To maintain and strengthen its positions in the world, including the level of income, savings and wealth, Russia must gain leader positions in the global markets of finished products, and services, which share in the world trade grows faster than the share of goods. In solving these vital questions no progress is observed, the right coherent policy isn't worked out. For the usage of the territorial potential it is important to develop the infrastructure, to create conditions for the implementation of business initiative, to change stereotypes in the service sector (information, transport, tourism). The updating of the creativity of citizens will be provided not only by economic, but also social and political conditions - freedom of creation and security of its results in the form of intellectual property, development of social relationships and confidence in the community, affordable and qualitative education, effective court system. Provision of these conditions should be an essential part of the development strategy.

The transition to a market economy, at least in the industry, if we mean the adaptation of enterprises to market conditions is over. But the process of modernization, if to associate it with the upgrade and capital accumulation, makes the first steps. Now we can count on a relatively liberal policy, on the modernization from the bottom as the only reasonable and promising course for the country. But we must bear in mind that these problems, including structural changes, will have to be solved within the limits imposed by this course.

No matter how to modernize the economy, it requires large investments. In Russia the savings rate is relatively high - more than $30 \%$ of GDP, but there is a low level of investments in the basic capital. Thus, the savings are slowly transformed into investments, and as a result the economic growth based on updating and capital increase, raising productivity is hindered. This means that, although the increase is based on the expansion of domestic demand, it will soon cease, because there will be no increase of revenue conditioned by increasing productivity. The alternative is a sharp increase in the effectiveness of the transformation of savings into investments, and rising investments itself. This conclusion is hardly new, but in the current circumstances it acquires special importance and urgency.

Since nowadays in Russia the mechanism of transformation of savings into investments is practically not working and also there is no intersectoral mobility of capital, then in such situation we can't talk about vital importance for the country of structural shifts in the economy, gaining positions in the markets of finished products and services. The country follows the tradition of a raw materials appendage with the prospect of reducing its role in the world markets.

In the most general terms, the solving of the problem of transformation of savings into investments is seen in the following:

- The accelerated development of the banking system as a key link;

- The growth of capitalization of the banking system as a basis for increasing the volume of lending;

- The creation of conditions to prevent capital flight;

- The increase of the money demand and money supply without the risk of inflation;

- Strengthening of the role of the stock market and its expansion to a scale that will allow it to become a stable mechanism of mobilizing investments.

The analysis of the current state of the investment environment has shown that at the present time in Russia there is a positive trend in investment activity. In January-September 2012 in Russia the investments in the basic capital increased at an annual rate of $7.2 \%$, according to preliminary estimates. However, many experts have pessimistic predictions based on an assessment of the situation in the world markets. The process of waiting for the next wave of the crisis has a negative impact on the formation of the banks' liabilities, including deposit component. Despite the fact that the rates on deposits have increased since the beginning of the year by an average of $1.5-2 \%$, and in reality, perhaps even more, there is no significant inflow of funds on deposits in banks. We don't observe the dynamics that should be according to the economic theory. Partly it can be explained by 
the fact that the population has not yet adapted to the new conditions of the economy.

Returning to the issue of crisis and innovations, it should be noted that, generally, the crisis is caused by a combination of destabilizing factors, the accumulation of which reaches a critical threshold. If an innovation that is able to resolve the crisis has appeared by this moment, it ends up by turning the direction while maintaining a more general paradigm of development. Such innovations are a kind of "response to the crisis" and they are usually based on the results of the evolution stage previous to the crisis, and therefore, they can't appear before the crisis. There are a lot of similar innovations and they form the basic mechanism of the progress.

Far less the number of innovations that are not directly connected to the current phase of development and traditional (generally adopted at this time) foundations of science and technology. Each "step aside" is a kind of miracle: a push to it may be a case or a contact with the parallel line of development. Consequently, the core of longterm development of territories should be the innovative breakthrough that will help to adapt human development to the realities of the XXI century, with the condition of the rejection of neoliberal illusions about the superiority of market self-regulation.

\section{CONCLUSIONS}

With regard to Russia the innovative breakthrough strategy is grounded in a number of monographs and draft long-term programs, but by this time these recommendations haven't found sufficient response from the government. Russia needs a real, not virtual (conservative) modernization, providing a radical innovation upgrade, increase of the competitiveness of the technological base of the economy. Over the past two decades, Russia has experienced several types of innovations, including anti-innovations (the reforms of the early 90's of the last century) and pseudo-innovations (the attempts of partial improvement of long outdated technologies). It is time to go to the basic innovations that can lead to radical changes in the decades and become a platform of epochal innovation developments that can provide a breakthrough in the scale of centuries.

\section{Works cited}

Blinov, A., Zakharov, V., \& Zakharov, I. (2012). Modyernizatsiya ekonomiki: yedinstvo tyehnologichyeskoy, obrazovatyel'noy i kommoonikatsionnoy stratyegiy. Problyemi tyeorii $i$ praktiki oopravlyeniya(4), 8-15.

Davydov, V. P., \& Grebenichenko, S. F. (2010). Kakaya tam yeshshye modyernizatsiya? SocgumZhurnal(2), 3-25. Retrieved from http://socgum-zhurnal.ru/index.php/cod/2010/number2

Kvasov, I. N. (2010). Osnovniye napravlyeniya sotroodnichyestva biznyesa i gosoodarstva $v$ voprosah modyernizatsii ekonomiki. Nats. intyeryesi: priorityeti i byezopasnost'(10), 27-36.

Volkova, N. S. (2010). Effyektivnost' prava i modyernizatsiya ekonomiki. Zhoornal rossiyskogo prava(2), 136-141.

Received for publication:

Revision received:

Accepted for publication:
21.11.2012

07.03 .2013

18.03.2013 


\section{How to cite this article?}

Style - APA Sixth Edition:

Prigoda, L. (2013, 07 15). Russia in the modernization: Financial aspect. (Z. Čekerevac, Ed.) FBIM Transactions, 1(2), 21-26. doi:10.12709/fbim.01.01.02.02

Style - Chicago Fifteenth Edition:

Prigoda, Ludmila. "Russia in the modernization: Financial aspect." Edited by Zoran Čekerevac. FBIM Transactions (MESTE) 1, no. 2 (07 2013): 21-26.

Style - GOST Name Sort:

Prigoda Ludmila Russia in the modernization: Financial aspect [Journal] = Russia in the modernization: Financial aspect // FBIM Transactions / ed. Čekerevac Zoran. - Belgrade : MESTE, 07 15, 2013. - 2 : Vol. 1. - pp. 21-26. - ISSN 2334-704X (Online); ISSN 2334-718X.

Style - Harvard Anglia:

Prigoda, L., 2013. Russia in the modernization: Financial aspect. FBIM Transactions, 15 07, 1(2), pp. 21-26.

Style - ISO 690 - Numerical Reference

Russia in the modernization: Financial aspect. Prigoda, Ludmila. [ed.] Zoran Čekerevac. 2, Belgrade : MESTE, 07 15, 2013, FBIM Transactions, Vol. 1, pp. 21-26. ISSN 2334-704X (Online); ISSN 2334-718X. 